\title{
Visibility of Religious Difference in Medieval Europe and the Mediterranean
}

Introductory remarks

Clara Almagro Vidal and Jörn Roland Christophersen

\section{OpenEdition \\ Journals}

\section{Electronic version}

URL: https://journals.openedition.org/hamsa/1049

DOI: 10.4000/hamsa.1049

ISSN: 2183-2633

\section{Publisher}

CIDEHUS - Centro Interdisciplinar de História Culturas e Sociedades da Universidade de Évora

\section{Electronic reference}

Clara Almagro Vidal and Jörn Roland Christophersen, "Visibility of Religious Difference in Medieval Europe and the Mediterranean ", Hamsa [Online], 7| 2021, Online since 02 September 2021, connection on 27 September 2021. URL: http://journals.openedition.org/hamsa/1049 ; DOI: https://doi.org/ 10.4000/hamsa.1049

This text was automatically generated on 27 September 2021.

\section{(c) (i)}

Hamsa est mise à disposition selon les termes de la Licence Creative Commons Attribution - Pas d'Utilisation Commerciale - Pas de Modification 4.0 International. 


\section{Visibility of Religious Difference in Medieval Europe and the Mediterranean}

Introductory remarks

Clara Almagro Vidal and Jörn Roland Christophersen

\section{Taking a closer look at visibility}

1 Visibility, that is to say, how one presents themself and how one is perceived, is an important marker of identity ${ }^{1}$. During the Middle Ages, religion was also a key element in a person's life. Religion encompassed moral and doctrinal implications, promised salvation or condemnation for individuals and groups, and shaped communities. It also contributed to the form of laws by which communities were ruled, as well as their ways of interacting with others and among themselves ${ }^{2}$. Consequently, a person's religion contributed to defining their position in society, their visibility, and, in many ways, conditioned how their interactions with adherents of other religions, that is interreligious contact, took place.

2 Visibility as it is understood for this monographic issue encompasses all perceptible aspects of a person or their actions. It is, in this sense, a very wide concept that extends beyond the merely physical. Although the visual aspect first comes to mind in the analysis of how religious groups became visible, the audible component was also important through for example language ${ }^{3}$, and calls to prayer". As such, "religious noise" was perceived and regulated during the Middle Ages. It was also denied, hidden, or not deemed worthy of mention ${ }^{5}$. Other aspects of religion, which influenced visibility include, for instance, that belonging to a certain religion had implications for the way that a person did business, as well as for the kinds of bonds they formed.

3 There are many definitions of the word "visibility", but the one provided by the Merriam-Webster Dictionary ${ }^{6}$ contains two aspects that are fundamental to the subject at hand: visibility is the state or fact of being visible; and also it is the capability of 
being readily noticed. One meaning puts the stress on the observed object itself (being visible) and the other on the observer (being noticed). Distinguishing this duality is significant for historical research because a significant temporal distance separates the researcher as observer from the observed objects (people in the past), and the historian's contemplation is not a direct one, but rather is filtered by the surviving sources. Both of these limit the historian's capacity for observation and interpretation of the observed.

Visibility is also determined by a number of variables that affect both the observer and the observed. We may not see things because they do not differentiate themselves from the whole (are not visible), because they are not there, because we do not know how to recognise them, or simply because we are not looking for them and do not notice them. Therefore, visibility depends on both the characteristics of the observed communities and on the biased perceptions thereof caused by the expectations of both the producers of our sources and of the researcher.

Both aspects go hand in hand most of the time; roughly speaking: the more visible something was at the time, the more visible it is to historians now. However, there are many ways in which this correlation may not apply, and circumstances in which the contemporary reality and the picture of it provided by extant evidence diverge. Likewise, images, signs and other perceptible elements could become detached from the community to which they had originally been associated. For example, visual features of Central European coins from the early and high Middle Ages suggest that they were made by Jews, since they bore Hebrew letters even though they were struck on behalf of the Christian overlords and for the use of everyone regardless of their religion. The effect of reminding the users of the coins of a special "Jewish expertise" remained, even when the Jews were not engaged in minting anymore ${ }^{7}$. Thereby, Jews were only imagined to be visible and a deeper layer of presence is constituted.

6 We encounter another deep layer of the presence of Jewish visibility in Christian theology ${ }^{8}$, which also could have shaped ideas about Jews living next to non-Jews. Theologically based anti-Judaism has - unsurprisingly, but not often with evidentiary bases - been postulated for areas in which no actual Jews were present ${ }^{9}$. Influences of ecclesiastical attitudes towards Jews and Muslims are best evidenced in the impositions of rules on clothing following the Fourth Lateran Council. Nevertheless, the actual impact of this on everyday life should be questioned. Rules of dress were renewed again and again but their practical application remained dependent on secular implementations of canon law.

7 Religious affiliation has traditionally revealed itself in particular ways, be that through images, structures, gestures, sounds, or even types of behaviour. During the Middle Ages - although not only then - these manifestations were deeply intertwined with cultural contexts and with political power. The particularities of the perceptible components that can be linked to one's religion were fundamental to the construction of individual and group identity, either through self-definition or imposition by others. That led, for example, to behaviours associated with religion that had a strong political component attached to them ${ }^{10}$, or, as the Inquisitorial records regarding former Muslims and Jews in late medieval and Early Modern Spain show, to the establishment of an equivalence between customs and appearance with religious attribution. For these reasons, external appearance - especially but not exclusively clothes and hairstyle - and the manifestation of cultural differences associated with religion were 
traditionally targeted to ensure the preservation of one's own identity and visual distinction from others ${ }^{11}$.

In this sense, observing the measures by which and terms according to which religious groups distinguished themselves and were free to exteriorise their singularity on their own terms, can become a useful base from which to evaluate the flexibility/inflexibility of interreligious coexistence ${ }^{12}$. Moreover, to self-presentation, and imposed visibility or invisibility, a third axis can be added to the analysis: the projection of a constructed image by third parties. In this respect, visibility could also be easily weaponised. Let us not forget how images and stereotyping has been used for a long time as a tool to promote certain discourses of rejection ${ }^{13}$ or promoting the alleged superiority of one's own religion ${ }^{14}$. This is especially true for stereotyped representation of religious groups, which, in turn, is usually not accurate.

Nevertheless, religion is by far not the only factor in defining perceptible traits of a group and neither is it always the main distinguishing feature. Even within one religious affiliation, geography and chronology also are important for how people present themselves ${ }^{15}$. Likewise, religious difference was not always obvious, neither to outsiders ${ }^{16}$ nor even to adherents of the same religious group. Repeated efforts to enact legislation aimed towards enforcing distinctive signs, speak clearly of this ambivalence. In addition, different levels of visibility could generate internal disparity within a community that was perceived from outside as one group but clearly contained more complexity. For example, despite sharing religious affiliation and being considered as one group by Christians, some Jews in the Middle Rhine valley, Germany, around 1400 may have considered that their brothers-in-faith from other nearby towns held different statuses to themselves, as legal and economic conditions changed from one dominion to the next, whether in secular lordships or ecclesiastical territories ${ }^{17}$.

Therefore, visibility reflects both self-identity construction and processes of othering. In this sense, visibility, both at an individual level and as a collective, functioned as a method of demarcation, as shown by the papers included in this issue. At the same time, the historical interpretation of that visibility is not linear. It rather should be interpreted, as we will see, together with the factors that produced it. Furthermore, it should be considered that our perception of the visibility of religious difference in the past is limited by biases, availability of sources and other factors that influence research.

\section{Visibility as a matter for interpretation of interreligious relations}

11 As pointed out above, visibility or lack thereof can be interpreted in different directions. For this reason, analysis should focus not only on the degree of visibility, but also ask for the functions or risks attached to the different levels and degrees of visibility.

Some only loosely connected observations may seem to contradict each other at first glance, but they represent the range and complexity of visibility as an object for analysis of interreligious relations. At the same time, it becomes clear that the statements not only consist of certainties but challenge our tolerance for ambiguity as different layers and different extents of visibility and invisibility are revealed. 

and leaves researchers with reflections about "expected" or "unexpected" visibility. Both visibility and invisibility can serve as a protection against or as a justification for aggression related to religious violence. For example, ritualised violence against Jews was sometimes linked to their visibility during religiously charged times ${ }^{18}$. On the other hand, a clearly perceptible legal status could have protective effects, as we see in Central Europe ${ }^{19}$, and as was connected to dhimmi status under Islam.

Likewise, the degree of visibility could be the result of different processes of regulation, depending on the level of agency in decision making of those affected by the measures in question. The degree could range from chosen to imposed when decision-making was unilateral. There could also be situations in between, where the measures were the result of negotiations between different actors.

On the one hand, visibility, when imposed from the outside, was a very important tool for marginalising groups that were perceived as foreign and/or a possible threat. For example, during the Fourth Lateran Council, a canon was issued stating that Jews and Muslims should wear distinctively visible signs on their clothes so that they could not possibly be mistaken for Christians ${ }^{20}$. In these cases, visibility carried the implication of marking the other as inferior, not trustworthy, or to be controlled, and the attempts to legislate were usually accompanied by other limiting regulations throughout medieval Europe $^{21}$. These regulations affected actual people who encountered each other.

While singling people out individually by forcing them to wear distinctive signs on their clothes, and limiting the types of materials and adornments that they could wear $^{22}$, there is little doubt that some of the segregating measures taken against Muslims and Jews in the Christian Kingdoms of the Iberian Peninsula also targeted the visibility of these religious groups as a collective by limiting their visual and audible projection ${ }^{23}$. Beyond the religious motivations and implications, these measures were also a way to display dominance over the members of the other religions. The use of spoliated headstones - a phenomenon we observe during the later Middle Ages throughout Europe when Christians used Jewish and Muslim tombstones as building material - therefore inverts the same system of limiting visibility by increasing the perceptibility of religiously relevant artefacts in new contexts; in this example, under domination and suppressed ${ }^{24}$.

On the other hand, differentiated visibility could also be created from within. In this process, it becomes clear that individual visibility or invisibility within one's own community in its places of assembly was crucial for sustaining the sense of belonging and therefore it was given significant weight ${ }^{25}$. It also allowed for a delicate balance between the visual particularities generated by one's own religion and the assimilation of traits that were common to the rest of society. In this sense, people of different religions shared fashions with the society in which they lived. Therefore, they were bound to appear to the outside as a mixture of their own particular attributes and characteristics common to the whole of that society.

\section{The papers in this issue}

This monographic issue highlights some of the ways in which religion marked a perceptible difference in medieval Europe and the Mediterranean. Considering 
visibility in the wider sense of the term, religion made people - either from their own will or under external coercion - visible within medieval societies. The tension between visibility through othering or self-labelling, and invisibility through cultural assimilation or through marginalisation was a constant in medieval urban and rural areas. This continued beyond the medieval period, sometimes reproducing previous problems, sometimes in the shape of new challenges.

four papers included in this dossier raise different issues on the topic of the visibility of religious difference. Their range and points of interest are different but complementary.

Ana Echevarria's paper is dedicated to the visibility of Muslims in Christian towns of medieval Iberia and the regulations enacted to police it. Interreligious cohabitation in urban contexts was a widespread phenomenon and left an imprint on the urban fabric. In the Christian kingdoms, this cohabitation at least in part resulted from the difficulties in attracting Christian settlers to newly conquered areas. Regulating spacial cohabitation became an ongoing task for the Christian authorities, who took measures to increasingly limit the visibility of Muslims and Jews in these contexts in a number of ways. They restricted where they could live and established walls that physically separated them from their Christian counterparts. In addition, authorities regulated the presence of already existing and newly built mosques and synagogues, as well as the visual and audible projection of non-Christian religious practice.

21 José-Luis Pascual approaches the issue of the visibility of Muslims in medieval Castile from a different perspective. Using the Muslim community of Arévalo and its most significant members as a case study, he explores features that characterised them and that set them apart from their Christian neighbours in the ways in which they operated. This happened in a number of manners. First, in the prolific ways in which they related to each other and created networks for their economic development among themselves and with Muslims from other geographic areas; second, their occupations; and finally the ways in which they prospered economically and socially. In doing so, he also hints towards the fact that, despite their tendency to interact and develop in-group economic networks, some members of this community became highly visible within Christian society through their service to the Crown.

For her part, Hadas Hirsch leads us through the roles attached to clothing and fashion under medieval Islam. Laws in Islam were closely interlinked with religion. For that reason, the legal texts issued in relation to materials, style and decoration of clothing had an important religious component. Using legal texts as a guide, Hirsch explores the arguments contained therein regarding materials, decorations, and other aspects of clothing, while pointing out the change of attitudes towards them across time and the uneven acceptance of external influences on a matter fundamental to the projection of self.

The last paper of this dossier, penned by Florian Jäckel, also focuses on regulations. In this case, about those that surrounded two key moments of life: the entrance into the religious community, and its exit through death. Barhebraeus was part of a Christian community living in the medieval Middle East and his writings were directed to them. However, as Jäckel shows, his texts explored the fluid and complex demarcation with Islam through the definition of the other and the acceptance or rejection of influences from Muslim rituals in a context of rich and close interactions. 
wider traditions that affect historians' work. Communities - and what is considered distinctive to them - which are registered in the written record, become visible for posterity, and enter historical memory as a group with particular characteristics. This forms a collective memorial tradition whenever a group is remembered as religiously different. Questions like these endure today because of particular relevances, for instance in the tourism industry. Through sometimes thoughtless or unconscious processes of reimagining, the presentation of juderias, Jewish quarters, and ghettos etc. highlight for tourists places to be thought about, even if these places and spaces reflect distorted versions of the past, as they are not representative of the former whole community or settlement areas. Talking about placesthat are still visible creates bridges to those markers of identity that refer to one particular community, such as the Jewish cemetery, and retains their visibility despite the individuals being long deceased. However, other, more nuanced, approaches can also link us to the past. In this sense, Pascual's take on religious difference points towards alternative ways in which this subject may be explored.

The study of visibility from different perspectives has proven to continue to be a fruitful field for research. The broad strokes, as well as the subtle nuances, that the essays bring out enrich our understanding of visibility and invisibility. Although the resulting picture is not by any means complete, it is our hope that it be useful to spark further and very necessary discussion on the topic. It will be in line with the advances and new developments in this direction, as shown by the fact that volumes recently published or that have been announced on the socio-historical relevance of perceptibility include new areas such as sound studies. ${ }^{26}$ This constitutes a very welcome widening of the scope of historical research that doubtlessly will enrichen the analysis of matters of religious difference, and will open new paths by which to get to the core of interreligious encounters in many facets. 


\section{Bibliography}

\section{Archival Sources}

Biblioteca Nacional de España, Madrid, Mss/8582.

\section{Bibliography and printed sources}

Disciplinary Decrees of the General Councils: Text, Translation and Commentary, trans. by H. J.

Schroeder, St. Louis and London, Herder Book, 1937, pp. 236-296.

Online edition of the Merriam Webster Dictionary: https://www.merriam-webster.com/dictionary/.

ALMAGRO VIDAL, Clara, “Nach dem Krieg: Grenzen religiöser Gewalt gegen Muslime in Ländern geistlicher Ritterorden auf der iberischen Halbinsel während des Mittelalters", in Historical Dimensions of Religious Violence, ed. Dorothea Weltecke (series Schriften des Historischen Kollegs), Munich, Oldenbourg, 2021 (forthcoming).

ARNOLD, John H., Belief and Unbelief in Medieval Europe, London and New York, Bloomsbury Academic, 2005.

BAUMGARTEN, Elisheva, Mothers and children. Jewish family life in medieval Europe (series Jews, Christians, and Muslims from the Ancient to the Modern World), Princeton, New Jersey, Princeton University Press, 2004.

BEINHAUER-KÖHLER, Bärbel, "Ritual performances to Install a New Coptic Patriarch in Twelfth Century Fatimid Cairo", in Religious Plurality and Interreligious Contacts in the Middle Ages, ed. Ana Echevarria Arsuaga and Dorothea Weltecke, Wiesbaden, Harrassowitz, 2020, pp. 125-136.

BUCARIA, Nicolò, “The Synagogue in Sicily. A Thousand Years' Story”, in Medieval Ashkenaz: Papers in Honour of Alfred Haverkamp Presented at the 17th World Congress of Jewish Studies, Jerusalem 2017, ed. Christoph M. Cluse and Jörg R. Müller, Wiesbaden, Harrassowitz, 2021 (series Forschungen zur Geschichte der Juden, Abt. A: Abhandlungen 31), pp. 413-432.

CASSASSAS, Xavier, "Contacto y convergencia interreligiosa en Tierra Santa en el siglo XV", in Religious Plurality and Interreligious Contacts in the Middle Ages, ed. Ana Echevarria Arsuaga and Dorothea Weltecke, Wiesbaden, Harrassowitz, 2020, pp. 137-156.

CHAZAN, Robert, The Jews of Medieval Western Christendom. 1000-1500 (series Cambridge medieval textbooks), Cambridge, Cambridge University Press, 2006.

CHRISTOPHERSEN, Jörn Roland, “BR01, No. 8”, in Corpus der Quellen zur Geschichte der Juden im spätmittelalterlichen Reich, ed. Alfred Haverkamp and Jörg R. Müller, Trier and Mainz, Akademie der Wissenschaften und der Literatur | Mainz, 2013; available online: http://www.medievalashkenaz.org/BR01/CP1-c1-0298.html.

CHRISTOPHERSEN, Jörn Roland, “'Under the crozier of Mainz'. Special Conditions for a Mobile Elite?", in Medieval Ashkenaz. Papers in Honour of Alfred Haverkamp Presented at the 17th World Congress of Jewish Studies, Jerusalem, 2017, ed. Christoph M. Cluse and Jörg R. Müller 
(series Forschungen zur Geschichte der Juden, Abt. A: Abhandlungen 31), Wiesbaden, Harrassowitz, 2021, pp. 48-62.

CHRISTOPHERSEN, Jörn Roland, Krisen, Chancen und Bedrohungen. Studien zur Geschichte der Juden in der Mark Brandenburg während des späteren Mittelalters (13. bis Anfang des 16. Jahrhunderts) (series Forschungen zur Geschichte der Juden, Abt. A: Abhandlungen), Wiesbaden, Harrassowitz, forthcoming 2021.

CUFFEL, Alexandra, Licia Di Giacinto, and Volkhard Krech (ed.), Senses, Religion, and Religious Encounter, Entangled Religions 10 (December 2019).

CUFFEL, Alexandra, Licia Di Giacinto, and Volkhard Krech, "Senses, Religion, and Religious Encounter: Literature Review and Research Perspectives", in Alexandra Cuffel, Licia Di Giacinto, and Volkhard Krech (ed.), Senses, Religion, and Religious Encounter, Entangled Religions 10 (December 2019). Available online: https://er.ceres.rub.de/index.php/ER/article/view/8407.

ECHEVARRIA ARSUAGA, Ana, "The Marks of the Other: the Impact of Lateran IV in the Regulations Governing Muslims in the Iberian Peninsula", in Jews and Muslims under the Fourth Lateran Council. Papers Commemorating the Octocentenary of the Fourth Lateran Council (1215), ed. Marie-Thérèse Champagne and Irven Resnick (series Religion and Law in Medieval Christian and Muslim Societies 10), Turnhout, Brepols, 2018, pp. 183-198.

ECHEVARRIA ARSUAGA, Ana, "La transformación del espacio islámico (siglos XI-XIII)", Cahiers d'Études Hispaniques Médiévales Année 15 (2003), pp. 53-77.

FRANCO LLOPIS, Borja, and Antonio Urquízar-Herrera, "Introduction", in Jews and Muslims Made Visible in Christian Iberia and Beyond, 14th to 18th Centuries, ed. Borja Franco Llopis and Antonio Urquízar-Herrera, Leiden and Boston, Brill, 2020, pp. 1-10.

FRANCO LLOPIS, Borja, and Antonio URQUÍZAR-HERRERA (eds.), Jews and Muslims Made Visible in Christian Iberia and Beyond, 14th to 18th Centuries, Leiden and Boston, Brill, 2020.

FREIDENREICH, David M., Foreigners and their food. Constructing otherness in Jewish, Christian, and Islamic law, Berkeley, University of California Press, 2011.

FRIEDMAN, Yvonne, "Christian Hatred of the Other: Theological Rhetoric vs. Political Reality", in Fear and loathing in the North. Jews and Muslims in medieval Scandinavia and the Baltic region, ed. Cordelia Heß and Jonathan Adams, Berlin, de Gruyter, 2015, pp. 187-201.

GADEA, Javier, "Espacios y manifestaciones materiales de los musulmanes castellanos: presencias y ausencias de una minoría medieval", Edad Media. Revista de Historia, 17 (2016), pp. 67-95.

GOITEIN, Shlomo Dov, A Mediterranean Society. The Jewish Communities of the Arab World as Portrayed in the Documents of the Cairo Geniza, Berkeley, Los Angeles, London, University of California Press, first paperback edition, vol. II, 1999.

HAVERKAMP, Eva, "Jewish Images on Christian Coins. Economy and Symbolism in Medieval Germany", in Jews and Christians in Medieval Europe. The Historiographical Legacy of Bernhard Blumenkranz, ed. Philippe Buc, Martha Keil, and John Victor Tolan (series Religion and Law in Medieval Christian and Muslim Societies 7), Turnhout, Brepols, 2016, pp. 189-226.

JASPERT, Nikolas and Harald MÜLLER (eds.), Klangräume des Mittelalters (series Vorträge und Forschungen), Ostfildern, Thorbecke, 2021 (forthcoming).

JASPERT, Nikolas, "Religious Movements in Mudejar Communities: Identity and Relational Dynamics in the Crown of Aragon", in Religious Plurality and Interreligious Contacts in the Middle Ages, ed. Ana Echevarria Arsuaga and Dorothea Weltecke, Wiesbaden, Harrassowitz, 2020, pp. 171-194. 
JASPERT, Nikolas, "Stiller Islam? Die akustischen Handlungsräume von Muslimen unter christlicher Herrschaft", in Klangräume des Mittelalters, ed. Nikolas Jaspert and Harald Müller (series Vorträge und Forschungen), Ostfildern, Thorbecke, 2021.

KISCH, Guido, The Jews in Medieval Germany. A Study of Their Legal and Social Status, $2^{\text {nd }}$ edition, Chicago, University of Chicago Press, 1970.

LINDER, Amnon, "The Jewry-Oath in Christian Europe", in Jews in Early Christian law. Byzantium and the Latin West, $6^{\text {th }}-11^{\text {th }}$ centuries, ed. John Victor Tolan, Nicholas de Lange, Laurence Foschia, and Capucine Nemo-Pekelman (series Religion and Law in Medieval Christian and Muslim Societies 2), Turnhout, Brepols, 2014, pp. 311-358.

LÜCK, Heiner, "Integration durch Recht. Flamen, Franken, Schwaben, Sachsen, Slawen und Juden im Entstehungsgebiet des Sachsenspiegels“, in Integrationskulturen in Europa, ed. Rüdiger Fikentscher (series mdv aktuell 9), Halle (Saale), Mitteldeutscher Verlag, 2014, pp. 72-100.

KISCH, Guido "The Sachsenspiegel and its Sources", The Germanic Revue 14 (1939), pp. 3-13.

MAGIN, Christine, "Wie es umb der iuden recht stet". Der Status der Juden in spätmittelalterlichen deutschen Rechtsbüchern, Göttingen, Wallstein, 1999.

PAHLITZSCH, Johannes, "The Melkites between Byzantium, Muslims and Crusaders", in Religious Plurality and Interreligious Contacts in the Middle Ages, ed. Ana Echevarria Arsuaga and Dorothea Weltecke, Wiesbaden, Harrassowitz, 2020, pp. 157-170.

REMIE-CONSTABLE, Olivia, "Regulating Religious Noise: The Council of Vienne, the Mosque Call and Muslim Pilgrimage in the Late Medieval Mediterranean World", Medieval Encounters, 16-1 (January 2010), pp. 64-95.

REMIE-CONSTABLE, Olivia, To live like a Moor. Christian Perceptions of Muslim Identity in Medieval and Early Modern Spain, ed. Robin Vose, Philadelphia, University of Pennsylvania Press, 2018.

RESNICK, Irven, “The Jew's Badge”, in Jews and Muslims under the Fourth Lateran Council. Papers Commemorating the Octocentenary of the Fourth Lateran Council (1215), ed. Marie-Thérèse Champagne and Irven Resnick (series Religion and Law in Medieval Christian and Muslim Societies 10), Turnhout, Brepols, 2018, pp. 65-80.

RÖCKELEIN, Hedwig, "Marienverehrung und Judenfeindlichkeit in Mittelalter und früher Neuzeit", in Maria in der Welt. Marienverehrung im Kontext der Sozialgeschichte ; 10.-18. Jahrhundert, ed. Claudia Opitz (series Clio Lucernensis 2), Zürich, Chronos, 1993, pp. 279-307.

RÖCKELEIN, Hedwig “'Die grabstain, so vil taథsent guldin wert sein'. Vom Umgang der Christen mit Synagogen und jüdischen Friedhöfen im Mittelalter und am Beginn der Neuzeit”, Aschkenas 5 (1995), pp. 11-45.

ROSSING, Daniel, “Dress”, in A dictionary of Jewish-Christian relations, ed. Edward Kessler and Neil Wenborn, Cambridge, Cambridge University Press, first paperback edition 2008, pp. 131-132.

RUIZ SOUZA, Juan Carlos, "Hispania, Al-Andalus and the Crown of Castile: Architecture and Constructions of Identity", in Jews and Muslims Made Visible in Christian Iberia and Beyond, $14^{\text {th }}$ to $18^{\text {th }}$ Centuries, ed. Borja Franco Llopis and Antonio Urquízar-Herrera, Leiden and Boston, Brill, 2020, pp. 121-138.

SHOHAM-STEINER, Ephraim, “'And in most of Their Business Transactions They Rely on This' Some Reflections on Jews and Oaths in the Commercial Arena in Medieval Europe", in On the Word of a Jew. Religion Reliability and the Dynamics of Trust, ed. Nina Caputo and Mitchell Hart, Bloomington, Indiana University Press, 2019, pp. 36-61, particularly pp.39-46. 
SHATZMILLER, Joseph, Cultural Exchange. Jews, Christians, and Art in the Medieval Marketplace (series Jews, Christians, and Muslims from the Ancient to the Modern World), Princeton and Oxford, Princeton University Press, 2013.

STOFFELS, Patrick Ewald, Die Wiederverwendung jüdischer Grabsteine im spätmittelalterlichen Reich (series Arye Maimon-Institut für Geschichte der Juden; Studien und Texte 5), Trier, Kliomedia, 2012.

WEINRYB, Bernard Dov, The Jews of Poland. A social and economic history of the Jewish community in Poland from 1100 to 1800, Philadelphia, The Jewish Publication Society of America, 1973.

WENNINGER, Markus J., “Die Juden in den Bilderhandschriften des Sachsenspiegels”, in Integration und Ausgrenzung. Studien zur deutsch-jüdischen Literatur- und Kulturgeschichte von der Frühen Neuzeit bis zur Gegenwart. Festschrift für Hans Otto Horch zum 65. Geburtstag, ed. Mark H. Gelber, Jakob Hessing and Robert Jütte, Tübingen, Niemeyer, 2009, pp. 2-17.

WIDDER, Ellen, Kanzler und Kanzleien im Spätmittelalter. Eine "Histoire croisée" fürstlicher Administration im Südwesten des Reiches (series Veröffentlichungen der Kommission für geschichtliche Landeskunde in Baden-Württemberg. Reihe B, Forschungen 204), Stuttgart, Kohlhammer, 2016, pp. 288-289.

WIEDL, Birgit, "Sacred Objects in Jewish Hands. Two Case Studies", in Jews and Christians in Medieval Europe. The Historiographical Legacy of Bernhard Blumenkranz, ed. Philippe Buc, Martha Keil, and John Victor Tolan (series Religion and Law in Medieval Christian and Muslim Societies 7), Turnhout, Brepols, 2016, pp. 57-77.

WIEDL, Birgit, “'Den Panzer von den Juden gekauft und empfangen.' Jüdische Lebensrealitäten zwischen Krieg und Katastrophen", in Krisen, Kriege, Katastrophen. Zum Umgang mit Angst und Bedrohung im Mittelalter, ed. Christian Rohr, Ursula Bieber, and Katharina Zeppezauer-Wachauer (series Interdisziplinäre Beiträge zu Mittelalter und Früher Neuzeit 3), Heidelberg, Winter, 2018, pp. 199-232.

ZIWES, Franz-Josef, “Territoriale Judenvertreibungen im Südwesten und Süden Deutschlands im 14. und 15. Jahrhundert", in Judenvertreibungen in Mittelalter und früher Neuzeit, ed. Friedhelm Burgard, Alfred Haverkamp, and Gerd Mentgen (series Forschungen zur Geschichte der Juden, Abt. A: Abhandlungen 9), Hannover, Hahn, 1999, pp. 165-187.

\section{NOTES}

1. We would like to express our gratitude to Jessica Tearney-Pearce (St. John's College, University of Cambridge) for her remarks, suggestions, and language rectifications throughout the editing of this introduction.

2. J. H. Arnold, Belief and Unbelief..., p. 106.

3. For example, Melkites thought that the language they used for prayer was in itself holy (J. Pahlitzsch, “The Melkites...”, p. 160).

On the use of vernacular languages in western and Central Europe, as well as under Muslim rule also see R. Chazan, The Jews of Medieval..., pp. 6, 13, 25, 78, 92, 102, 117, 118, 205, 206, 224, 266. Chazan's loose selection already indicates a certain relevance to previous research in the observation of language use as distinctive for certain groups or not.

4. In particular, the call for prayer was often a point of contention between Muslims and Christians (on the Christian side, the Council of Vienne prohibited the Muslim call for prayer on 
Christian lands and this was enacted in the laws of the kingdoms. See O. Remie-Constable, "Regulating Religious Noise...". It even entered the diplomatic issues between Muhammad I of Egypt and Jaume II of Aragon. N. Jaspert, "Religious Movements...", pp. 183 and 191. About the regulation of the audible projection of Muslims on Christian lands, see also N. Jaspert, "Stiller Islam?". We thank the author for allowing us to read his paper before publication.

5. In the many documents from the Cairo Genizah arranged by Shlomo Dov Goitein, it is only once that a muezzin seemed to be worth mentioning (S.D. Goitein, A Mediterranean Society, p. 452according to the index in vol. VI, ed. S. D. Goitein and Paula Sanders, p. 76). That does not mean that the Jews of the Mediterranean did not notice the Muslim call for prayer. Maybe they simply did not name it or maybe, for Goitein (and those who worked on the index) the Muslim call for prayer was not to be connected with the term muezzin that is contained in the index. This constellation reveals one of the many problems addressed by this collective volume: the interest in perceiving the differences in appearances is not only biased by the sources themselves but by the focus of modern research, as well.

6. The relevant definitions are "the quality or state of being visible" and "capability of being readily noticed". Online edition of the Merriam Webster Dictionary (retrieved 26 March 2021).

7. For the whole complex, see with many examples: E. Haverkamp, “Jewish Images...".

8. Weinryb, for Poland in premodern times, made a difference between "The Actual Jew" and "The Theological Jew" (B.D. Weinryb, The Jews of Poland..., p. 11-12).

9. See Y. Friedman, “Christian Hatred...", especially at p.193 (with concise wording). See furthermore: D. M. Freidenreich, Foreigners and their food..., for instance at p. 10.

10. A good example has been analysed by B. Beinhauer-Köhler, "Ritual performances...".

11. O. Remie-Constable, To live like a Moor..., analyses this kind of targeting in relation to Muslims under Christian Rule in Castile and the Crown of Aragon.

12. In multireligious contexts, outward manifestations attached to a religion that was predominant and/or associated to power would be freer than those associated to those who were not in that position. For example, Christian pilgrims, upon arrival to Jerusalem in the second half of the $15^{\text {th }}$ century, were told to contain their impulse to pray and sing aloud, lest they irritated Muslims around them. This contrasts with the freedom to express themselves enjoyed by Muslims arriving to Mecca during that same time (X. Cassassas, "Contacto y convergencia interreligiosa...", pp. 145-146).

13. B. Franco Llopis and A. Urquízar-Herrera, "Introduction", p. 2, remark on the use of the physical description of the Arabs to induce fear by archbishop Jiménez de Rada in his 13th century chronicle De Rebus Hispaniae.

14. Several examples can be found B. Franco Llopis and A. Urquízar-Herrera (eds.) Jews and Muslims...

15. B. Franco Llopis and A. Urquízar-Herrera, "Introduction", p. 8. On this aspect, it has been remarked referring to the medieval Iberian Peninsula that "mere adherence to religion does not imply unity, and there were regional, political, cultural and linguistic differences that were unaligned with religion" O. R. Constable, To live like a Moor..., p. 5.

16. For example, the European pilgrim Felix Fabri, upon arrival to Jerusalem in the last quarter of the 15th century, remarked in his account of the trip on the difficulty in distinguishing between the Muslims and the Oriental Christians who looked after the Orchard of Matariyya in Egypt (X. Cassassas, "Contacto y convergencia...", p. 154.

17. J. R. Christophersen, “'Under the crozier...", pp. 56 and 60-61.

18. For example, the ordinances issued in the general chapter of the Order of Santiago of 1440 contain a rule that stated that a certain level of violence against their houses was allowed without penalty only if Jews were found out in the open during the Holy Days. Biblioteca Nacional de España, Mss/8582, fol. 173v-174r. Available online: http://bdh.bne.es/bnesearch/ detalle/bdh0000060492 (cit. C. Almagro Vidal, “Nach dem Krieg...”). 
19. The Sachsenspiegel, a $13^{\text {th }}$ century Saxon law book in some of the German speaking lands, for example, knows a royal punishment (death penalty) for those who kill Jews in full conscience of deliberately attacking Jews (because this broke the "Königsfriede", that is: the king's peace, or the "Landfriede"), but a less harsh and less symbolic punishment for those who did not aim to attack a Jewish person but did hurt a Jew fatally. See H. Lück, "Integration durch Recht...“, p. 83. Guido Kisch brought his excellent knowledge of the medieval Saxon law into English language research, and, for a long time, his works remained the most relevant on all aspects related to German-Jewish history. See - among many more of his studies - G. Kisch, The Jews..., pp. 171-302, and G. Kisch, "The Sachsenspiegel...". In German-language research, an enacted paradigm shift can be traced back to Magin who, much more than older studies, asked for the real background and handling of the statements from law books and custumals. See C. Magin, "Wie es umb der iuden... In this place, it can only be mentioned that illustrated manuscripts of the Sachsenspiegel depict Jews, with broad implications for their visibility. The study of the image-text interplay and consideration of the chosen iconography has a particular potential for insight. For initial access to this, see J. Shatzmiller, Cultural Exchange..., pp.37-38, M.J. Wenninger, "Die Juden in den Bilderhandschriften...", p. 12, and B. Wiedl, "Sacred Objects...", pp. 63 and 64.

20. Canon 68 stated, "In nonnullis provinciis a christianis Iudæos seu Saracenos habitus distinguit diversitas sed in quibusdam sic quædam inolevit confusio ut nulla differentia discernantur. Unde contingit interdum quod per errorem christiani Iudæorum seu Saracenorum et Iudæi seu Saraceni christianorum mulieribus commisceantur. Ne igitur tam damnatæ commixtionis excessus per velamentum erroris huiusmodi excusationis ulterius possint habere diffugium statuimus ut tales utriusque sexus in omni christianorum provincia et omni tempore qualitate habitus publice ab aliis populis distinguantur cum etiam per Moysen hoc ipsum legatur eis iniunctum. In diebus autem lamentationis et dominicæ passionis in publicum minime prodeant eo quod nonnulli ex ipsis talibus diebus sicut accepimus ornatius non erubescunt incedere ac christianis qui sacratissimæ passionis memoriam exhibentes lamentationis signa prætendunt illudere non formidant. Illud autem districtissime inhibemus ne in contumeliam redemptoris prosilire aliquatenus præsumant. Et quoniam illius dissimulare non debemus opprobrium qui probra nostra delevit præcipimus præsumptores huiusmodi per principes sæculares condignæ animadversionis adiectione compesci ne crucifixum pro nobis præsumant aliquatenus blasphemare". Disciplinary Decrees..., pp. 236-296. For an initial breakdown of the canon's implications, see D. Rossing, "Dress".

21. For example, Christians should not force Jews to deliver an oath in front of the Thora Ark in 15th century Malta in what called Bucaria "minor cases" (see N. Bucaria, "The Synagogue in Sicily...", p. 415. We know, as well, that Jews should deliver the oath in front of the synagogue and in German language, not in Hebrew (lingua theutonica ita quod christiani universi suum intelligant iuramentum), in 13th century northern Germany (the source document has been published by J.R. Christophersen, "BR01, No. 8". Obviously, this legal instrument of making a solemn vow was meant to be fully perceptible by Christians and Jews alike. On oath-making by Jews see A. Linder, "The Jewry-Oath ...". On Jews vowing in front of Christians on the central-European market, see E. Shoham-Steiner, “"And in most of Their Business ...”, pp.39-46.

22. I. Resnick, “The Jew's Badge”. Also, on the implementation of the regulations of appearance on Muslims in medieval Castile, see A. Echevarria Arsuaga, "The Marks of the Other...".

23. Ana Echevarria explores this phenomenon in her article about Christian towns of the Iberian Peninsula in this monographic issue.

24. Comparable effects go with re-dedications of mosques as churches (as widely attested in the Iberian Peninsula. See A. Echevarria Arsuaga, "La transformación del espacio...") and synagogues for Our-Lady-chapels (e.g. Regensburg, Germany, and Cologne, Germany, the latter with the chapel of the council) or universities (e.g. Frankfurt on the Oder, Heidelberg, both in Germany) or of Slavonic pagan shrines for churches (e.g. St. Mary's, Brandenburg on the Havel, Germany, 
following the temple of Triglav).

On various aspects of Jewish-Christian relations in the north-east German speaking lands during the Middle Ages see: J.R. Christophersen, Krisen, Chancen und Bedrohungen... On the transformations of synagogues into churches dedicated to Mary, see H. Röckelein, "Marienverehrung und Judenfeindlichkeit...". Ziwes used various examples to illustrate the interactions between expulsions of Jews, the founding of universities and early humanism, see: F.-J. Ziwes, “Territoriale Judenvertreibungen...". Anti-Semitic opinions and polemics can be found again and again at universities in the vicinity of persecutions, for example in connection with the catastrophe of the Viennese Geserah, see B. Wiedl, “'Den Panzer von den Juden...”, p. 220. In Heidelberg, four Jewish gravestones from the cleared Jewish cemetery were transferred in 1391 to the protonotary Matthias von Sobernheim by the main beneficiary of the pogrom, the newly founded university. See E. Widder, Kanzler und Kanzleien..., pp. 288-289. For an overview on re-used headstones in the medieval Holy Roman Empire see Patrick E. Stoffels, Die Wiederverwendung.... For more detailled argumentations see H. Röckelein, “'Die grabstain...”. For some examples on the relocation of Muslim tombstones in Christian churches, see J. Gadea, "Espacios y manifestaciones...", especially p. 73. Although such reuses could be motivated by mere convenience, it could also be intentional. In secular contexts, the appropriation of architectural elements in buildings associated to power, both in al-Andalus and the Christian kingdoms, was meant to send a clear message of superiority of the authority that incorporated the spolia in their own constructions see J.C. Ruiz Souza, "Hispania, Al-Andalus and the Crown of Castile...". This point has also been made for Christian Europe by J.H. Arnold, Belief and Unbelief..., p. 52 .

25. Being publicly seen in church or in the synagogue was important for women who had given birth and therefore needed a renewal of initiation rites. Baumgarten has identified these rituals after childbirth on the day of rest. See E. Baumgarten, Mothers and children..., p. 110.

26. For example, the monographic issue edited by A. Cuffel, L. Di Giacinto and V. Krech, Senses, Religion.... The issue includes a state of the art on the topic, see A. Cuffel, L. Di Giacinto, and V. Krech, "Senses, Religion...", accessed 30.04.2021). Also, N. Jaspert and H. Müller (eds.), Klangräume....

\section{ABSTRACTS}

This introduction presents the rationale for this monographic issue. The idea of visibility and its many aspects and implications are explored as a framework, offering suggestions for accessing this subject. Additionally, it provides an overview of the different contributions included in this issue, and links them with the overarching ideas and with each other in a comparative manner.

A introdução apresenta o justificativo desta edição monográfica. A ideia de visibilidade e seus múltiplos aspectos e implicações é explorada como um referencial, oferecendo pistas para abordagem do assunto. Além disso, fornece uma visão das diferentes contribuições incluídas nesta edição, e relaciona-as com as ideias gerais e de forma comparativa. 
INDEX

Palavras-chave: visibilidade, metodologia, relações interreligiosas, diferença religiosa, Idade Média

Keywords: visibility, methodology, interreligious relations, religious difference, Middle Ages

\section{AUTHORS}

CLARA ALMAGRO VIDAL

Goethe Universität Frankfurt am Main

almagrovidal@em.uni-frankfurt.de

JÖRN ROLAND CHRISTOPHERSEN

Goethe Universität Frankfurt am Main

christophersen@em.uni-frankfurt.de 